\title{
Factors Affecting Dengue Fever among the Population in Bandar Maharani, Muar, Johor, Malaysia
}

\author{
Article by Roy Rillera Marzo ${ }^{1}$, Lee Chin Ying ${ }^{2}$, Mah Li Hui ${ }^{2}$ \\ ${ }^{1}$ Deputy Dean, Asia Metropolitan University, Master in Public Health, Fellow in \\ Public Health \\ ${ }^{2}$ MBBS, Asia Metropolitan University \\ Email:-rrmtexas@yahoo.com
}

\begin{abstract}
Background: Dengue is a mosquito-borne viral disease. The trend of dengue incidence in Malaysia has continued to increase since 2001 until 2014. Despite the close monitoring and continuous efforts from the Ministry of Health and Municipals to conduct the prevention and control activities, the number of dengue cases continued to increase due to multiple uncontrolled factors.

Aim: Our objective is to assess the factors affecting dengue fever among the population in Bandar Maharani, Muar, Johor, Malaysia.

Methodology: A descriptive, cross-sectional study design based on simple random sampling, resident aged between 18 to 60 years old was randomly chosen. Data was collected using assisted self-administered questionnaire that covered 4 parts i.e. socio-demographic data, knowledge about dengue infection, attitudes towards dengue fever and practices of dengue prevention. Data was analyzed using PASW statistics student version 18.

Results: It was found that knowledge among the respondent was only moderate. The respondents' attitude was neutral and the practice was good. The most common source of information on dengue was from the television (72.1\%). There was significant association between knowledge and practice $(p=0.000)$ and also between attitude and practice $(p=$ $0.000)$. Attitude was associated with ethnicity $(p=0.002)$ and education level $(p=0.031)$.

Conclusion: The study has highlighted that despite having satisfactory level of practice on dengue prevention, the knowledge and attitude can be further strengthened. Information, education and communication materials can be provided at areas that are more accessible. This would help to increase knowledge and mold positive attitude among the Muarian to eliminate dengue fever.
\end{abstract}

Keywords: Dengue Fever, Knowledge, Attitude, Practice, Malaysia

\section{Introduction}

Dengue is a mosquito-borne disease caused by any one of four closely related dengue viruses (DEN-1, -2, -3 , and -4).The mosquito-borne infection especially dengue, had become a global health problem in Asia, the Americas and the Western Pacific. The infection has turn intoendemic with repeated epidemic outbreaks in many parts of the tropics and subtropical regions of the world (World Health Organization, 2014).

Dengue virus, a flavivirus in the family of Togaviridae is transmitted to humans by the bite of infected Aedes. Aedesaegypti mosquito serves as a main vector for the transmission of the virus. It is found in urban area while Aedesalbopictus predominates in the rural setting (Pang T et al, 1983; Lam SK, 1993).

Today about 2.5 billion people or $40 \%$ of the world population are living in areas with high risk of dengue transmission. Dengue is endemic in at least 100 countries in Asia, the Pacific, the Americas, Africa, and the Caribbean. The World Health Organization (WHO) estimates that 50 to 100 million infections occurs yearly, including 500,000 DHF cases and 22,000 deaths, mostly among children (Centers for Disease Control and Prevention, 2015). 
South American Journal of Public Health

Volume 4, Issue 1, 2016

Since the first reported case of dengue fever in Malaysia in 1902, dengue has remained a serious public health problem in this country (Li Ping Wong et al, 2014).A series of outbreak reported in 1973 with 54 deaths out of 1,487 cases, 1974 with 104 deaths out of 2,200 cases and 1982 with 35 deaths out of 3,006 cases reported. Since year 2002, the number of dengue cases and incidence rate continue to increase with the highest ever reported in 2014 (Rose NaniMudin, 2015). Dengue is rated the most important communicable disease in Malaysia, superseding tuberculosis, malaria and HIV/AIDS (Shepard DS et al, 2013).

Malaysia started to implement the National Strategic Plan for Dengue (2009-2013) targeting to reduce the cases of dengue by half in a duration of 5 years. The strengthening on dengue prevention and control is carried throughout 7 strategies: (i) surveillance system, (ii) integrated vector management, (iii) dengue case management, (iv) communication and social mobilization, (v) dengue outbreak response, (vi) dengue research and (vii) dengue strategic plan (Ministry of Health, 2010). However, gaps still exist where even with high knowledge, attitude, practice within the community; dengue fever still remains to be a problem and is currently on the increasing fashion (Anita AbdRahman et al, 2014).

For development of a suitable health education strategy, it is necessary to understand the level of perception and knowledge of the community regarding dengue fever, the attitude and practices the people follow to prevent from dengue fever (K. Ravi Kumar et al, 2005).

\section{Aim of this Study}

\section{General objective}

To assess the factors affecting dengue fever among the population in Bandar Maharani, Muar, Johor, Malaysia.

\section{Specific objectives}

1. To determine the knowledge, attitude, and practice of dengue fever among Muarian.

2. To determine the association between socio-demographic characteristics with knowledge, attitude and practice of dengue fever among Muarian.

3. To determine the association between knowledge and practice of dengue fever among Muarian.

4. To determine the association between attitude and practice of dengue fever among Muarian.

5. To determine the sources of information.

\section{Methodology}

\section{Study design}

This was a descriptive, cross-sectional study of perception, knowledge, attitudes and practices concerning dengue among communities of Bandar Maharani, Johor, Malaysia.

\section{Study population}

The population in this study was residents of Bandar Maharani who were aged between 18-60 and were living there for at least one year.

\section{Study area}

Bandar Maharani was selected as the study area due to the high population density and availability of adequate data. 


\section{Study period}

From 2nd to 4th week of November, 2015.

\section{Sample size}

A computed sample size of 383 respondents was required to fulfill the objective of the study at a $95 \%$ confidence level assuming $5 \%$ of confidence interval.

\section{Sampling method}

Bandar Maharani was chosen among the 11 districts of Johor by simple random sampling. Bandar Maharani has a total number of 127,905 populations. A total of 10 residential areas in Bandar Maharani were selected randomly by random sampling software. In every residential area, odd number was chosen. Each members of the selected household was interviewed.

\section{Ethical considerations}

Approval of the study was obtained from the Medical Research Ethics Committee (MREC) of Asia Metropolitan University, Selangor, Malaysia. Informed the participants about the purpose and design of the study and assured that participation was voluntary and confidential. Written consent was obtained from those who agreed to participate.

\section{Research instrument and Measurement}

Data was collected by using a validated questionnaire which was developed from literature for the use in this study (Nahida Ahmed, 2007). The questions were directed towards gaining information regarding the community's knowledge, attitude and practice on dengue fever. The questionnaire was translated from English to Bahasa Malaysia and Mandarin without altering the original meaning which was verified by Bahasa Malaysia and Mandarin teachers.

The questionnaire consisted of 4 parts:

The first part consisted of information regarding demographic data such as age, gender, educational level, marital status, ethnicity and employment status.

The second part included questions on knowledge about dengue infection. This was assessed by 14 questions and the response option included 'yes' or 'no'. A correct answer was given 1 score and 0 score for the wrong answer. The score varies from 0 14 points and classified into 3 levels as follows:

\begin{tabular}{|c|c|}
\hline High level (80-100\%) & $12-14$ scores \\
\hline Moderate level (60-79\%) & 9-11 scores \\
\hline Low levels (less than 59\%) & $0-8$ scores \\
\hline
\end{tabular}

The third part assessed the attitudes towards dengue fever and it included 12 questions, assessing by using Likert's Scale. There were 12 statements which includes both positive and negative. The rating scale measured as follows:

\begin{tabular}{lc|lc}
\multicolumn{2}{c|}{ Positive Statement } & \multicolumn{2}{c}{ Negative Statement } \\
\hline Choice & Score & Choice & Score \\
Strongly agree & 5 & Strongly agree & 1 \\
Agree & 4 & Agree & 2 \\
Neither agree nor disagree & 3 & Neither agree nor disagree & 3 \\
Disagree & 2 & Disagree & 4 \\
Strongly disagree & 1 & Strongly disagree & 5
\end{tabular}

The score varies from 12 to 60 and all individual answers were summed up for total scores and calculated for means. The scores were classified into 3 levels: 
South American Journal of Public Health

Volume 4, Issue 1, 2016

$\begin{array}{ll}\text { Positive Attitude } & 47-60 \text { scores } \\ \text { Neutral Attitude } & 41-46 \text { scores } \\ \text { Negative Attitude } & 12-40 \text { scores }\end{array}$

The fourth part addressed practices of dengue prevention which was assessed by 13 questions and the response options included 'yes', 'no' and 'do not have'. The variables gave zero for 'no' and value one for 'yes'. (Based on Bloom's cut off point, $60-80 \%)$

$\begin{array}{ll}\text { Good level } & \text { 9-13 scores } \\ \text { Fair level } & \text { 5-8 scores } \\ \text { Poor level } & \text { 0-4 scores }\end{array}$

\section{Data analysis procedures}

The collected information was entered in Excel sheet and interpreted by using PASW Statistics Student Version 18. Summed up the questions on knowledge, attitudes, and practices and obtained the total score of each part. Data analysis including descriptive statistics (frequency, percentage, mean and standard deviation) was used to summarize and describe the data. Chi-square was used for analytical statistic to describe the relationship between two variables.

\section{Frequency distribution in term of}

- Socio-demographic characteristics

- Level of knowledge

- Attitude towards dengue fever

- $\quad$ Practice regarding dengue fever prevention

\section{Association between:}

- Socio-demographic characteristics with knowledge, attitude and practice

- Knowledge and practice

- Attitude and practice

\section{Results}

\section{Demographic information}

A total of 383 populations of Bandar Maharani, Muar participated in the study. Table 1 shows the socio-demographic characteristics of respondents. The mean age of the study participants was 30.64 years, with a standard deviation of 10.19 . The age ranged from 18 to 60 years old. There were more female (60.8\%) than males (39.2\%) in this study. More than half of the respondents (64.8\%) were married. Most of the study participants had a secondary school education (77.3\%) while $13.6 \%$ were undergraduates. Of the total respondents, $73.4 \%$ were employed. The majority (42.0\%) had a monthly income of RM 900 to RM 1500. Most of the participants were Malay (64.5\%) with Chinese and Indians at $31.6 \%$ and $2.1 \%$ respectively. The remaining consisted of other ethnic minorities (1.8\%).

Table 1. Socio-demographic characteristics of respondents ( $\mathrm{N}=383$ )

\begin{tabular}{|c|c|c|c|}
\hline Characteristic & $\boldsymbol{n ( \% )}$ & Characteristic & $\boldsymbol{n}(\%)$ \\
\hline \multicolumn{2}{|c|}{ Gender } & \multicolumn{2}{|c|}{ Employment Status } \\
\hline Male & $150(39.2)$ & Employed & $281(73.4)$ \\
\hline Female & $233(60.8)$ & Unemployed & $102(26.2)$ \\
\hline \multicolumn{2}{|c|}{ Age Groups (years) } & \multicolumn{2}{c|}{ Income } \\
\hline $18-30$ & $260(67.9)$ & None & $108(28.2)$ \\
\hline $31-43$ & $65(17)$ & RM 900-RM1500 & $161(42)$ \\
\hline
\end{tabular}


Volume 4, Issue 1, 2016

\begin{tabular}{|c|c|c|c|}
\hline $44-56$ & $40(10.4)$ & $\begin{array}{c}\text { RM 1500- } \\
\text { RM3000 }\end{array}$ & $76(19.8)$ \\
\hline$>56$ & $18(4.7)$ & Above RM3000 & $38(9.9)$ \\
\hline \multicolumn{2}{|c|}{ Marital Status } & \multicolumn{2}{|c|}{ Ethnicity } \\
\hline Single & $248(64.8)$ & Malay & $247(64.5)$ \\
\hline Married & $123(32.1)$ & Chinese & $121(31.6)$ \\
\hline Divorced & $6(1.6)$ & Indian & $8(2.1)$ \\
\hline Widow & $6(1.6)$ & Others & $7(1.8)$ \\
\hline \multicolumn{4}{|c|}{ Educational Level } \\
\hline Primary & $16(4.2)$ & & \\
\hline Secondary & $296(77.3)$ & & \\
\hline Graduate & $52(13.6)$ & & \\
\hline Post-graduate & $19(5.0)$ & & \\
\hline
\end{tabular}

\section{Source of information regarding dengue fever}

The respondents were allowed to select more than one source of information about dengue fever. The main source of information given by the participants was television (72.1\%) followed by radio $(45.7 \%)$ and leaflets $(33.7 \%)$. The most under-utilized source of information was from friends (16.7\%).

Table 2. Sources of information regarding dengue fever and the percentage of respondents.

\begin{tabular}{|c|c|c|}
\hline Sources & $\mathrm{n}$ & $\%$ \\
\hline Television & 276 & 72.1 \\
\hline Radio & 175 & 45.7 \\
\hline Leaflets & 129 & 33.7 \\
\hline Family & 96 & 25.1 \\
\hline Magazines & 95 & 24.8 \\
\hline Newspaper & 89 & 23.2 \\
\hline Others & 73 & 19.1 \\
\hline Friends & 64 & 16.7 \\
\hline
\end{tabular}

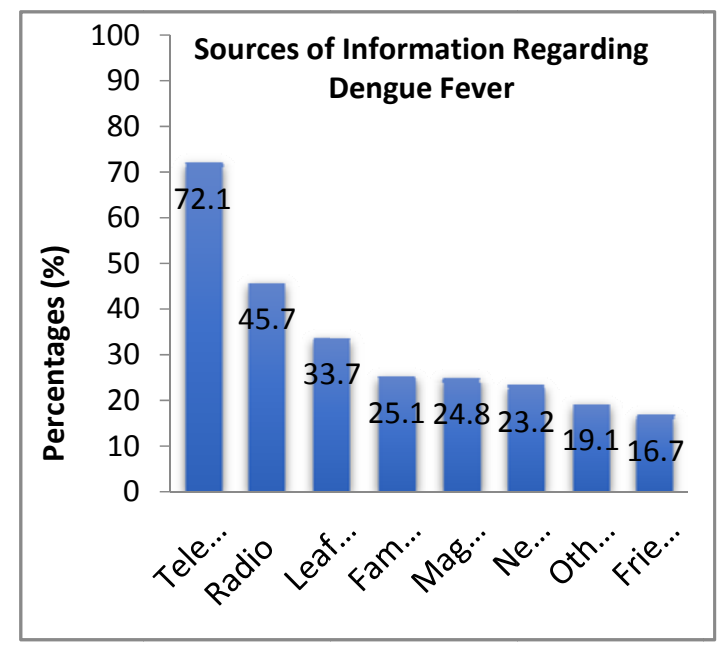

Graph 1. Sources of information regarding dengue fever and the percentage of respondents.

\section{Knowledge about dengue infection}

In the survey questionnaire, there were 14 questions related to knowledge of dengue fever. One point was given to each correct response. The mean total knowledge score for the overall sample was 4.73 with a standard deviation of 1.76, 
South American Journal of Public Health

Volume 4, Issue 1, 2016

out of possible 14 points. The response for the 14 knowledge part of the questionnaire was summarized in Table 4. Only one respondent was able to answer all the questions correctly.

The range of knowledge score was $0-14$ as shown in Table 3 . It showed that $62.9 \%$ of the participants had moderate level of knowledge, 21.2\% had low knowledge and $15.9 \%$ had high knowledge. Approximately all of the participants (97.4\%) were aware that empty stagnant water from old tires, trash cans, and flower pots can be breeding places for mosquitoes. Three hundred and fifty one of the respondents (91.6\%) knew that the principal mosquito vector for dengue fever is Aedesaegypti. More than half of the participants (85.1\%) knew that the symptoms of dengue are chills, headache, pain upon moving the eyes and low backache. However, more than half of the participants (64.5\%) wrongly answered that dengue mosquito lays eggs in dirty sewage water. Only $24.5 \%$ of the participants knew that mosquito transmitting infection bites only during day time.

Table 3. Knowledge about dengue infection; number and percentage of respondent based on the option given.

\begin{tabular}{|l|c|c|}
\hline \multicolumn{1}{|c|}{ Questions } & \multicolumn{2}{|c|}{$\begin{array}{c}\text { Number of respondents } \\
\text { (\%) }\end{array}$} \\
\cline { 2 - 3 } & Yes & No \\
\hline $\begin{array}{l}\text { 1. The principal mosquito vector for dengue fever is } \\
\text { Aedesaegypti. }\end{array}$ & $351(91.6)$ & $32(8.4)$ \\
\hline $\begin{array}{l}\text { 2. Dengue fever is a severe, flu-like illness that } \\
\text { affects infants, young children and adults. }\end{array}$ & $300(78.3)$ & $83(21.7)$ \\
\hline $\begin{array}{l}\text { 3. Dengue patients have chills, headache, pain upon } \\
\text { moving the eyes, and low backache. }\end{array}$ & $326(85.1)$ & $57(14.9)$ \\
\hline $\begin{array}{l}\text { 4. Rainy season is the only epidemic season for } \\
\text { dengue infection. }\end{array}$ & $241(62.9)$ & $142(37.1)$ \\
\hline $\begin{array}{l}\text { 5. Mosquitoes transmitting dengue infection bites } \\
\text { only during day time. }\end{array}$ & $94(24.5)$ & $289(75.5)$ \\
\hline $\begin{array}{l}\text { 6. The mosquito that transmits dengue infection } \\
\text { lays its eggs in dirty sewage water. }\end{array}$ & $247(64.5)$ & $136(35.5)$ \\
\hline $\begin{array}{l}\text { 7. Empty stagnant water from old tires, trash cans, } \\
\text { and flower pots can be breeding places for } \\
\text { mosquitoes. }\end{array}$ & $373(97.4)$ & $10(2.6)$ \\
\hline $\begin{array}{l}\text { 8. Dengue viruses are transmitted to human through } \\
\text { bites of infective female Aedes mosquitoes. }\end{array}$ & $286(74.4)$ & $97(25.3)$ \\
\hline $\begin{array}{l}\text { 9. Only method of controlling dengue infection is to } \\
\text { combat the vector mosquitoes. }\end{array}$ & $323(84.3)$ & $60(15.7)$ \\
\hline $\begin{array}{l}\text { 10. There is no specific treatment for dengue } \\
\text { infection and the drug of choice is paracetamol. }\end{array}$ & $162(42.3)$ & $221(57.7)$ \\
\hline $\begin{array}{l}\text { 11. Abate sand can be beneficial in killing the } \\
\text { mosquito larvae. }\end{array}$ & $315(82.2)$ & $68(17.8)$ \\
\hline $\begin{array}{l}\text { 12. Abate sand, if put in the standing water, can } \\
\text { help prevent the mosquito breeding for 3 months. }\end{array}$ & $281(73.4)$ & $102(26.6)$ \\
\hline $\begin{array}{l}\text { 13. Stored water containers/ tanks for drinking } \\
\text { water without being covered should be cleaned } \\
\text { every 7 days. }\end{array}$ & $307(80.2)$ & $76(19.8)$ \\
\hline $\begin{array}{l}\text { 14. I am afraid of getting dengue fever if one of my } \\
\text { family members has dengue fever. }\end{array}$ & $320(83.6)$ & $63(16.4)$ \\
\hline
\end{tabular}


Table 4. Knowledge about dengue infection; number and percentage of the respondents based on the score.

\begin{tabular}{|l|c|c|}
\hline \multicolumn{2}{|c|}{ Level } & Number of respondents (\%) \\
\hline High (80-100\%) & 12-14 scores & $61(15.9)$ \\
\hline Moderate (60-79\%) & $9-11$ scores & $241(62.9)$ \\
\hline Low (less than 59\%) & $0-8$ scores & $81(21.2)$ \\
\hline Minimum & $=4$ \\
Maximum & $=14$ \\
Mean & $=4.73$ \\
Standard deviation & $=1.76$
\end{tabular}

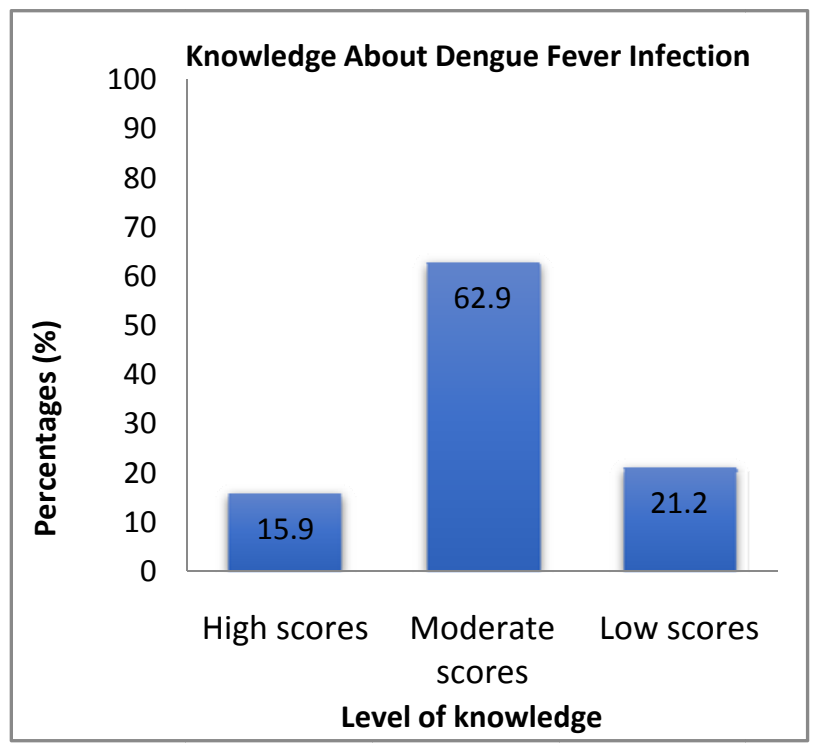

Graph 2. Number and percentage of the respondent's knowledge about dengue fever infection based on the scores.

\section{Attitude towards dengue fever}

The participants answered a total of 12 questions related to the attitude towards dengue fever, which had a total score of 60 . The distribution of attitudes toward dengue fever is shown in Table 6 . There were $44.1 \%$ of participants who had "neutral attitude", $37.9 \%$ had "negative attitude" while $18.0 \%$ had positive attitude. The mean larval breeding sources is a waste of time and very complicated while more than half of the participants (56.4\%) disagreed that person who once got dengue infection cannot be infected again. Fifty-four percent of participants disagreed that strong and healthy person will not get dengue infection. When asked about the possibility to recover completely from dengue infection, $48.0 \%$ of the respondents agreed and $1.3 \%$ of the respondents were strongly disagreed that the only method of controlling or preventing dengue and dengue hemorrhagic fever is to combat the vector mosquitoes.

Table 5. Attitude towards dengue infections, number of respondents based on the options given.

\begin{tabular}{|l|l|l|l|c|l|}
\hline Questions & \multicolumn{5}{|c|}{ Number of respondents (\%) } \\
\cline { 2 - 6 } & $\begin{array}{l}\text { Strongly } \\
\text { Agree }\end{array}$ & Agree & $\begin{array}{l}\text { Neither } \\
\text { agree nor } \\
\text { Disagree }\end{array}$ & Disagree & $\begin{array}{l}\text { Strongly } \\
\text { Disagree }\end{array}$ \\
\hline $\begin{array}{l}\text { 1. Dengue fever is a } \\
\text { disease that cannot } \\
\text { be prevented. }\end{array}$ & $37(9.7)$ & $\begin{array}{c}103 \\
(26.9)\end{array}$ & $37(9.7)$ & 142 & $64(16.7)$ \\
\hline 2. Eliminating the & $99(25.8)$ & $93(24.3)$ & $34(8.9)$ & 105 & $52(13.6)$ \\
\hline
\end{tabular}


South American Journal of Public Health

Volume 4, Issue 1, 2016

\begin{tabular}{|c|c|c|c|c|c|}
\hline $\begin{array}{l}\text { breeding places is } \\
\text { the responsibility of } \\
\text { the public health } \\
\text { staff and health } \\
\text { volunteer. }\end{array}$ & & & & (27.4) & \\
\hline $\begin{array}{l}\text { 3. Only method of } \\
\text { controlling or } \\
\text { preventing dengue } \\
\text { and dengue } \\
\text { hemorrhagic fever is } \\
\text { to combat the vector } \\
\text { mosquitoes. }\end{array}$ & $\begin{array}{c}123 \\
(32.1)\end{array}$ & $\begin{array}{c}172 \\
(44.9)\end{array}$ & $48(12.5)$ & $35(9.1)$ & $5(1.3)$ \\
\hline $\begin{array}{l}\text { 4. Only smogging is } \\
\text { enough to prevent } \\
\text { mosquito and no } \\
\text { need for other ways. }\end{array}$ & $23(6.0)$ & 60 (15.7) & $58(15.1)$ & $\begin{array}{c}190 \\
(49.6)\end{array}$ & $52(13.6)$ \\
\hline $\begin{array}{l}\text { 5. Everybody has a } \\
\text { chance to be infected } \\
\text { with dengue virus. }\end{array}$ & $76(19.8)$ & $\begin{array}{c}192 \\
(50.1)\end{array}$ & $41(10.7)$ & $52(13.6)$ & $22(5.7)$ \\
\hline $\begin{array}{l}\text { 6. Person who once } \\
\text { got dengue infection } \\
\text { cannot get dengue } \\
\text { infection again. }\end{array}$ & $19(5.0)$ & $30(7.8)$ & $52(13.6)$ & $\begin{array}{c}216 \\
(56.4)\end{array}$ & $66(17.2)$ \\
\hline $\begin{array}{l}7 . \text { It is possible to } \\
\text { recover completely } \\
\text { from } \\
\text { infection. }\end{array}$ & 55 (14.4) & $\begin{array}{c}184 \\
(48.0)\end{array}$ & 57 (14.9) & 74 (19.3) & $13(3.4)$ \\
\hline $\begin{array}{l}\text { 8. Elimination of } \\
\text { larval breeding } \\
\text { sources is a waste of } \\
\text { time and very } \\
\text { complicated. }\end{array}$ & $8(2.1)$ & $35(9.1)$ & $43(11.2)$ & $\begin{array}{c}153 \\
(39.9)\end{array}$ & $144(37.6)$ \\
\hline $\begin{array}{l}\text { 9. Restricting and } \\
\text { checking the } \\
\text { availability } \\
\text { potential breeding } \\
\text { habits should be } \\
\text { conducted every } 1-2 \\
\text { times/year. }\end{array}$ & $33(8.6)$ & $\begin{array}{c}110 \\
(28.7)\end{array}$ & $63(16.4)$ & $\begin{array}{c}126 \\
(32.9)\end{array}$ & $51(13.3)$ \\
\hline $\begin{array}{l}10 . \text { Strong and } \\
\text { healthy person will } \\
\text { not get dengue } \\
\text { infection. }\end{array}$ & $17(4.4)$ & $39(10.2)$ & $39(10.2)$ & $\begin{array}{c}207 \\
(54.0)\end{array}$ & $81(21.1)$ \\
\hline $\begin{array}{lr}\text { 11. Sleeping } & \text { in } \\
\text { mosquito net can } \\
\text { prevent } \\
\text { infection. }\end{array}$ & $41(10.7)$ & $\begin{array}{c}154 \\
(40.2)\end{array}$ & $65(17.0)$ & $98(25.6)$ & $25(6.5)$ \\
\hline $\begin{array}{l}\text { 12. You are one of } \\
\text { the important people } \\
\text { in preventing dengue } \\
\text { fever. }\end{array}$ & $\begin{array}{c}124 \\
(32.4)\end{array}$ & $\begin{array}{c}173 \\
(45.2)\end{array}$ & $62(16.2)$ & $14(3.7)$ & $10(2.6)$ \\
\hline
\end{tabular}


Table 6. Attitude towards dengue fever; number and percentages of respondents based on the scores.

\begin{tabular}{|c|c|c|}
\hline \multicolumn{2}{|c|}{ Level } & Number of \\
\hline Positive Attitude & 47-60 scores & $69(18.0)$ \\
\hline Neutral Attitude & 41-46 scores & $169(44.1)$ \\
\hline Negative Attitude & 12-40 scores & $145(37.9)$ \\
\hline $\begin{array}{l}\text { Minimum } \\
\text { Maximum } \\
\text { Mean } \\
\text { SD }\end{array}$ & $\begin{array}{l}77 \\
66 \\
11.93 \\
1.99\end{array}$ & \\
\hline
\end{tabular}

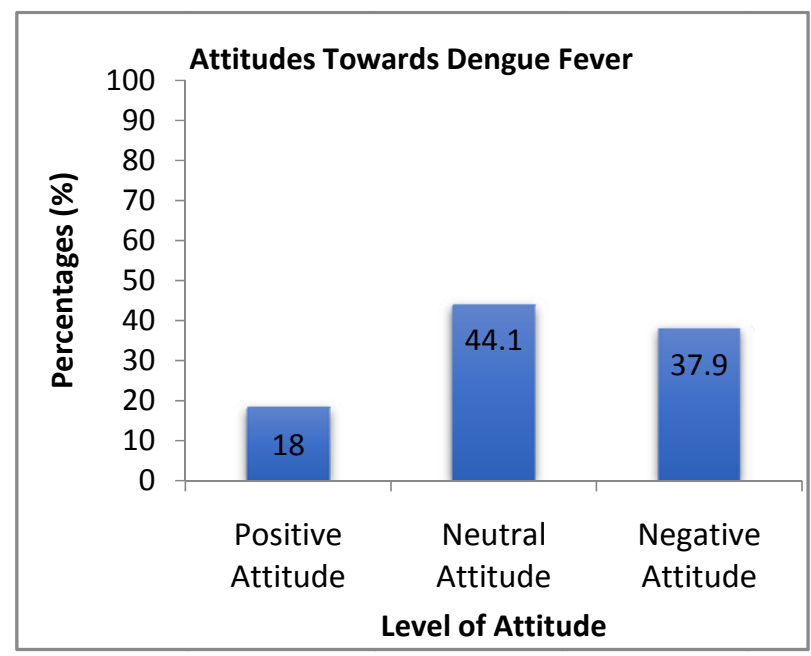

Graph 3. Number and percentages of respondent's attitude towards dengue fever based on the scores.

\section{Practice regarding dengue infection}

Participants answered a total of 13 questions. Each correct response was given one mark with a total score of 13 . The total scores are added up and distributed to three levels which are poor practice, fair practice and good practice. The mean practice score was 8.46 out of possible 13 points with a standard deviation of 2.65. The distribution of practice regarding dengue infection was presented in Table 8. Majority of the respondents, 52.3\% had "good practice", $40 \%$ had "fair practice" and only 7.5\% had "poor practice". Table 7 shows respondents' practices regarding dengue infection. Majority of the respondents (86.2\%) had a cover for their water tanks and $88.5 \%$ of them removed the mosquito larvae if it is found in the water tank. Three hundred and thirty four respondents (87.2\%) disposed any discarded thing that can hold water around their house. About $86.7 \%$ of the respondents covered the water jar immediately after used. Approximately, only $39.4 \%$ of the respondents checked and cleaned the roof gutters in the raining season. 
South American Journal of Public Health

Volume 4, Issue 1, 2016

Table 7. Practice regarding dengue infection; number and percentages of respondents based on the options given.

\begin{tabular}{|c|c|c|c|}
\hline \multirow[t]{2}{*}{ Questions } & \multicolumn{3}{|c|}{ Number of respondents (\%) } \\
\hline & Yes & No & $\begin{array}{l}\text { Don't } \\
\text { have }\end{array}$ \\
\hline $\begin{array}{l}\text { 1. Do you cover water jars after using } \\
\text { immediately? }\end{array}$ & $332(86.7)$ & $39(10.2)$ & $12(3.1)$ \\
\hline $\begin{array}{l}\text { 2. Do you have a cover in your water } \\
\text { tanks? }\end{array}$ & $330(86.2)$ & $31(8.1)$ & $22(5.7)$ \\
\hline $\begin{array}{l}\text { 3. If there is a mosquito larvae in your } \\
\text { water tank, do you ever do anything to } \\
\text { get rid of it? }\end{array}$ & $339(88.5)$ & $21(5.5)$ & $23(6.0)$ \\
\hline $\begin{array}{l}\text { 4. Do you ever examine the mosquito } \\
\text { larvae in the flower pots? }\end{array}$ & $248(64.8)$ & $76(19.8)$ & $58(15.1)$ \\
\hline $\begin{array}{l}\text { 5. Do you change the water of the } \\
\text { indoor plants every week? }\end{array}$ & $228(59.5)$ & $80(20.9)$ & 75 (19.6) \\
\hline $\begin{array}{l}\text { 6. Do you ever drain off the water in } \\
\text { the plates of the flower pot? }\end{array}$ & $230(60.1)$ & $83(21.7)$ & $69(18.0)$ \\
\hline $\begin{array}{l}\text { 7. Do you examine any discarded } \\
\text { thing that can hold water around your } \\
\text { house? }\end{array}$ & $296(77.3)$ & $60(15.7)$ & $26(6.8)$ \\
\hline $\begin{array}{l}\text { 8. If yes, do you ever put them in the } \\
\text { garbage or dispose them? }\end{array}$ & $334(87.2)$ & $28(7.3)$ & $21(5.5)$ \\
\hline $\begin{array}{l}\text { 9. Do you use mosquito net/ mosquito } \\
\text { coils in your house? }\end{array}$ & $208(54.3)$ & $114(29.8)$ & $61(15.9)$ \\
\hline $\begin{array}{l}\text { 10. Do you participate when your } \\
\text { community has been sprayed fog? }\end{array}$ & $126(32.9)$ & $219(57.2)$ & $38(9.9)$ \\
\hline $\begin{array}{l}11 . \text { Do you participate in any } \\
\text { campaigns of dengue infection in your } \\
\text { community? }\end{array}$ & $131(34.2)$ & 208 (54.3) & $44(11.5)$ \\
\hline $\begin{array}{l}\text { 12. Do you ever examine the mosquito } \\
\text { larvae in water containers in the toilet? }\end{array}$ & $295(77.0)$ & $68(17.8)$ & $20(5.2)$ \\
\hline $\begin{array}{l}\text { 13. Do you check and clean your roof } \\
\text { gutters in the rainy season? }\end{array}$ & $151(39.4)$ & $185(48.3)$ & $47(12.3)$ \\
\hline
\end{tabular}

Table 8. Practice regarding dengue infection; number and percentages of respondents based on the scores.

\begin{tabular}{|c|c|c|}
\hline Level & \multicolumn{2}{|c|}{ Number of respondents (\%) } \\
\hline Good & 9-13 scores & $201(52.5)$ \\
\hline Fair & $5-8$ scores & $153(40.0)$ \\
\hline Poor & $0-4$ scores & $29(7.5)$ \\
\hline
\end{tabular}




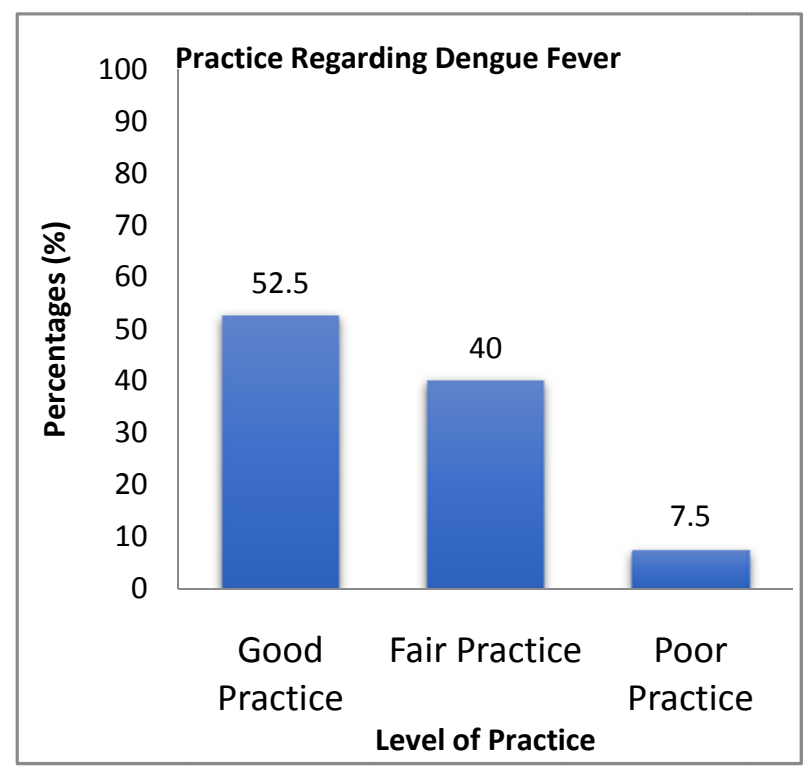

Graph 4. Number and percentages of respondents practice regarding dengue infection based on the scores.

\section{Association between knowledge, attitude and practice about dengue infection and socio-} demographic variables

Chi-square test was used to determine the association between socio-demographic variables and knowledge of dengue infection in Bandar Maharani, Muar population. The following tables (Table 9 to 13) provide the details of these tests.

As shown in Table 9 there was no association between socio-demographic and level of knowledge.

Table 9. Association between socio-demographic variables and knowledge about dengue fever infection.

\begin{tabular}{|c|c|c|c|c|c|}
\hline \multirow{2}{*}{\multicolumn{2}{|c|}{$\begin{array}{l}\text { Socio-demographic } \\
\text { variables }\end{array}$}} & \multicolumn{3}{|c|}{ Knowledge } & \multirow{2}{*}{$\begin{array}{l}\text { Total } \\
\text { n (\%) }\end{array}$} \\
\hline & & \multirow{2}{*}{$\begin{array}{c}\begin{array}{c}\text { High } \\
\text { n }(\%)\end{array} \\
38(14.6)\end{array}$} & \multirow{2}{*}{$\begin{array}{c}\text { Moderate } \\
\text { n (\%) }\end{array}$} & \multirow{2}{*}{$\begin{array}{c}\text { Low } \\
\text { n (\%) }\end{array}$} & \\
\hline Age & $18-30$ & & & & $260(100)$ \\
\hline & $31-43$ & $13(20.3)$ & 38 (58.5) & $14(21.5)$ & 65 (100) \\
\hline & $44-56$ & $7(17.5)$ & $24(60.0)$ & $9(22.5)$ & $40(100)$ \\
\hline & $>56$ & $3(16.7)$ & $10(55.6)$ & $5(27.8)$ & $18(100)$ \\
\hline \multirow[t]{2}{*}{ Gender } & Male & $38(25.3)$ & $76(50.7)$ & $36(24.0)$ & $150(100)$ \\
\hline & $\begin{array}{c}\text { Femal } \\
\mathrm{e}\end{array}$ & $23(9.9)$ & $165(70.8)$ & 45 (19.3) & $233(100)$ \\
\hline \multirow[t]{4}{*}{ Marital Status } & Single & $37(14.9)$ & $157(63.3)$ & $54(21.8)$ & $248(100)$ \\
\hline & $\begin{array}{c}\text { Marrie } \\
\mathrm{d}\end{array}$ & $21(17.1)$ & $77(62.6)$ & $25(20.3)$ & $123(100)$ \\
\hline & $\begin{array}{c}\text { Divorc } \\
\text { ed }\end{array}$ & $2(33.3)$ & $3(50.0)$ & 1 (16.7) & $6(100)$ \\
\hline & $\begin{array}{l}\text { Wido } \\
\text { wed }\end{array}$ & $1(16.7))$ & $4(66.7)$ & 1 (16.7) & $6(100)$ \\
\hline \multirow[t]{3}{*}{ Education Level } & $\begin{array}{c}\text { Primar } \\
\mathrm{y}\end{array}$ & $2(12.5)$ & $8(50.0)$ & $6(37.5)$ & $16(100)$ \\
\hline & $\begin{array}{l}\text { Secon } \\
\text { dary }\end{array}$ & $45(15.2)$ & $185(62.5)$ & $66(22.3)$ & $296(100)$ \\
\hline & Gradu & $12(23.1)$ & $34(65.4)$ & $6(11.5)$ & $52(100)$ \\
\hline
\end{tabular}


South American Journal of Public Health

Volume 4, Issue 1, 2016

\begin{tabular}{|c|c|c|c|c|c|}
\hline & \multicolumn{2}{|l|}{ ate } & & \multirow[b]{2}{*}{$3(15.8)$} & \multirow[b]{2}{*}{$19(100)$} \\
\hline & $\begin{array}{l}\text { Post- } \\
\text { gradua } \\
\text { te }\end{array}$ & $2(10.5)$ & 14 (73.7) & & \\
\hline \multirow[t]{2}{*}{$\begin{array}{l}\text { Employment } \\
\text { Status }\end{array}$} & $\begin{array}{c}\text { Emplo } \\
\text { yed }\end{array}$ & 38 (13.5) & $193(68.7)$ & $50(17.8)$ & $281(100)$ \\
\hline & $\begin{array}{l}\text { Unem } \\
\text { ployed }\end{array}$ & $23(22.5)$ & $48(47.1)$ & $31(30.4)$ & $102(100)$ \\
\hline \multirow[t]{4}{*}{ Income } & None & $23(21.3)$ & $55(50.9)$ & $30(27.8)$ & $108(100)$ \\
\hline & $\begin{array}{c}\text { RM90 } \\
0-1500\end{array}$ & $16(9.9)$ & $116(72.0)$ & $29(18.0)$ & $161(100)$ \\
\hline & $\begin{array}{c}\text { RM15 } \\
00- \\
3000\end{array}$ & $13(17.1)$ & $47(61.8)$ & $16(21.1)$ & $76(100)$ \\
\hline & $\begin{array}{c}>\mathrm{RM} 3 \\
000\end{array}$ & $9(23.7)$ & $23(60.5)$ & $6(15.8)$ & $38(100)$ \\
\hline \multirow[t]{4}{*}{ Ethnicity } & Malay & 45 (18.2) & $150(60.7)$ & $52(21.1)$ & $247(100)$ \\
\hline & Indian & $1(12.5)$ & $6(75.0)$ & $1(12.5)$ & $8(100)$ \\
\hline & $\begin{array}{c}\text { Chines } \\
\mathrm{e}\end{array}$ & $15(12.4)$ & $83(68.6)$ & $23(19.0)$ & $121(100)$ \\
\hline & Others & $0(0)$ & $2(28.6)$ & $5(71.4)$ & $7(100)$ \\
\hline \multicolumn{2}{|l|}{ Total } & 61 (15.9) & $241(62.9)$ & $81(21.1)$ & $383(100)$ \\
\hline
\end{tabular}

As shown in Table 11, a significant association was found between attitude scores and ethnicity $(p=0.002)$. Education level also had association with level of attitude among the respondents in this study $(\mathrm{p}=0.031)$.

Table 10. Association between socio-demographic variables and attitudes towards dengue fever infection.

\begin{tabular}{|c|c|c|c|c|c|}
\hline \multicolumn{2}{|c|}{ Socio-demographic variables } & \multicolumn{3}{|c|}{ Practice } & \multirow{2}{*}{$\begin{array}{l}\text { Total } \\
\text { n (\%) }\end{array}$} \\
\hline & & $\begin{array}{c}\text { Positive } \\
\text { n (\%) }\end{array}$ & $\begin{array}{c}\text { Neutral } \\
\text { n (\%) }\end{array}$ & $\begin{array}{c}\text { Negative } \\
\text { n (\%) }\end{array}$ & \\
\hline \multirow[t]{4}{*}{ Age } & $18-30$ & $137(52.7)$ & $109(41.9)$ & $14(5.4)$ & $260(100)$ \\
\hline & $31-43$ & $36(55.4)$ & $20(30.8)$ & $9(13.8)$ & $65(100)$ \\
\hline & $44-56$ & $19(47.5)$ & $16(40.0)$ & $5(12.5)$ & $40(100)$ \\
\hline & $>56$ & $9(50.0)$ & $8(44.4)$ & $1(5.6)$ & $18(100)$ \\
\hline \multirow{4}{*}{$\begin{array}{l}\text { Educational } \\
\text { Level }\end{array}$} & Primary & $2(12.5)$ & $6(37.5)$ & $8(50.0)$ & $16(100)$ \\
\hline & Secondary & $50(16.9)$ & $128(43.2)$ & $118(39.9)$ & $296(100)$ \\
\hline & Graduate & $14(26.9)$ & $23(44.2)$ & $15(28.8)$ & $52(100)$ \\
\hline & $\begin{array}{c}\text { Post- } \\
\text { graduate }\end{array}$ & $3(15.8)$ & $12(63.2)$ & $4(21.1)$ & $19(100)$ \\
\hline \multirow{2}{*}{$\begin{array}{l}\text { Employment } \\
\text { Status }\end{array}$} & Employed & $43(15.3)$ & $132(47.0)$ & $106(37.7)$ & $281(100)$ \\
\hline & $\begin{array}{c}\text { Unemploy } \\
\text { ed }\end{array}$ & $26(25.5)$ & $37(36.3)$ & $39(38.2)$ & $102(100)$ \\
\hline \multirow[t]{4}{*}{ Income } & None & $27(25.0)$ & $41(38.0)$ & $40(37.0)$ & $108(100)$ \\
\hline & $\begin{array}{c}\text { RM900- } \\
1500 \\
\end{array}$ & $20(12.4)$ & $77(47.8)$ & $64(39.8)$ & $161(100)$ \\
\hline & $\begin{array}{l}\text { RM1500- } \\
3000\end{array}$ & $13(17.1)$ & $35(46.1)$ & $28(36.8)$ & $76(100)$ \\
\hline & >RM3000 & $9(23.7)$ & $16(42.1)$ & $13(34.2)$ & $38(100)$ \\
\hline \multirow[t]{2}{*}{ Ethnicity } & Malay & $53(21.5)$ & $112(45.3)$ & $82(33.2)$ & $247(100)$ \\
\hline & Indian & $1(12.5)$ & $2(25.0)$ & $5(62.5)$ & $8(100)$ \\
\hline
\end{tabular}




\begin{tabular}{|r|c|c|c|c|c|}
\hline & Chinese & $15(12.4)$ & $54(44.6)$ & $52(43.0)$ & $121(100)$ \\
\cline { 2 - 6 } & Others & $0(0)$ & $1(14.3)$ & $6(85.7)$ & $7(100)$ \\
\hline Total & $69(18.0)$ & $169(44.1)$ & $145(37.9)$ & $383(100)$ \\
\hline
\end{tabular}

With regards to practices, there was a significant association between education level and practice scores $(\mathrm{p}=0.020)$ as shown in Table 11 .

Table 11. Association between socio-demographic variables and practices towards dengue fever infection.

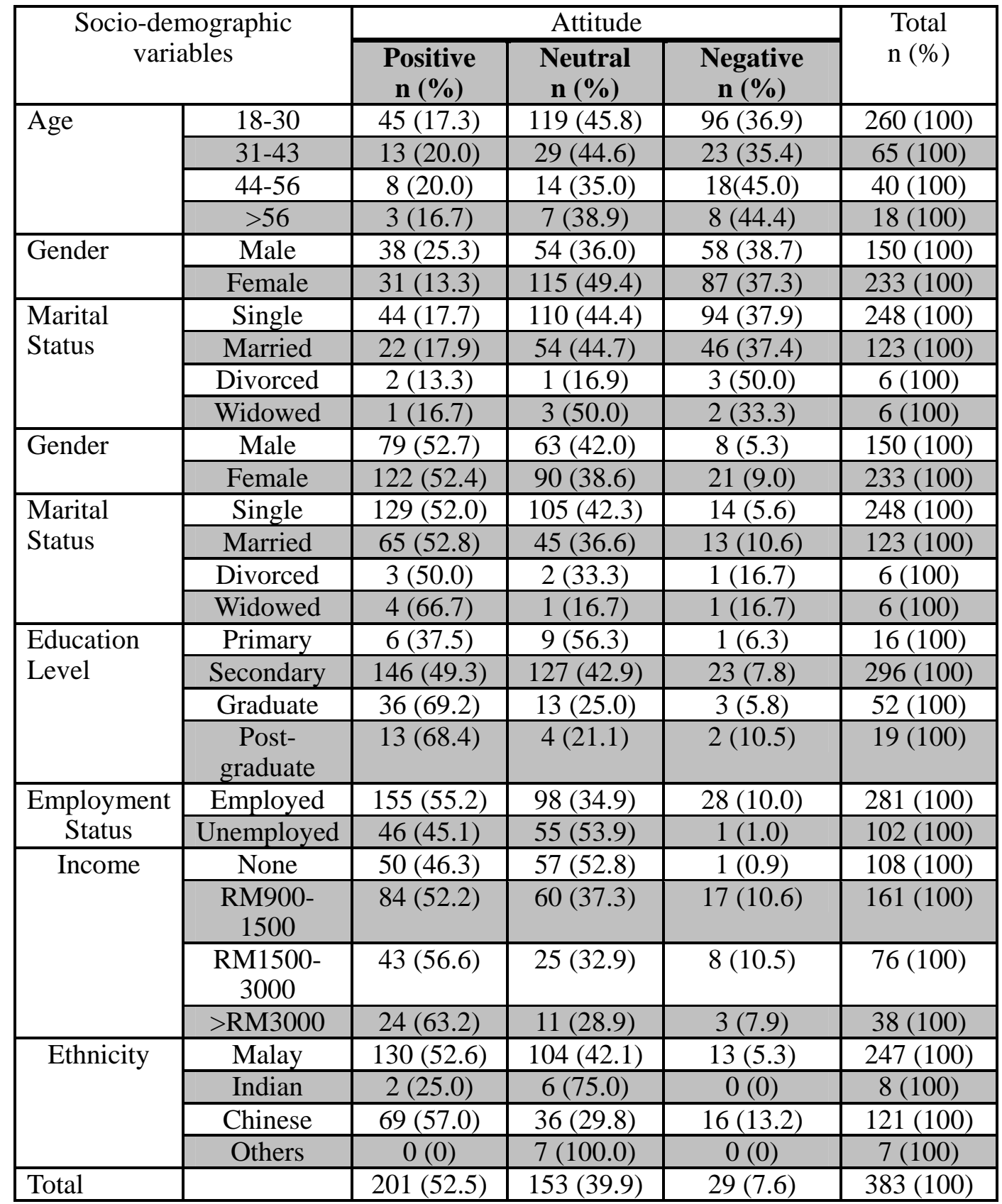

As shown in Table 12, knowledge had highly statistically significant association with level of practice behaviors regarding dengue infection $(p=0.00)$. 
South American Journal of Public Health

Volume 4, Issue 1, 2016

Table 12. Association between knowledge and level of practice against dengue fever prevention.

\begin{tabular}{|c|c|c|c|c|}
\hline \multirow[t]{2}{*}{ Level } & \multicolumn{4}{|c|}{ Knowledge } \\
\hline & $\begin{array}{c}\text { Low } \\
\text { No. (\%) }\end{array}$ & $\begin{array}{c}\text { Moderate } \\
\text { No. (\%) }\end{array}$ & $\begin{array}{l}\text { High } \\
\text { No. } \\
(\%)\end{array}$ & $\begin{array}{c}\text { Total } \\
\text { No. }(\%)\end{array}$ \\
\hline Poor practice & $29(100)$ & $0(0)$ & $0(0)$ & $29(100)$ \\
\hline Fair practice & $52(34.0)$ & $101(66.0)$ & $0(0)$ & $153(100)$ \\
\hline Good practice & $0(0)$ & $140(69.7)$ & $\begin{array}{c}61 \\
(30.3)\end{array}$ & $201(100)$ \\
\hline Total & $81(21.1)$ & 241 (62.9) & $\begin{array}{c}61 \\
(15.9)\end{array}$ & $383(100)$ \\
\hline 0.000 & & & & \\
\hline
\end{tabular}

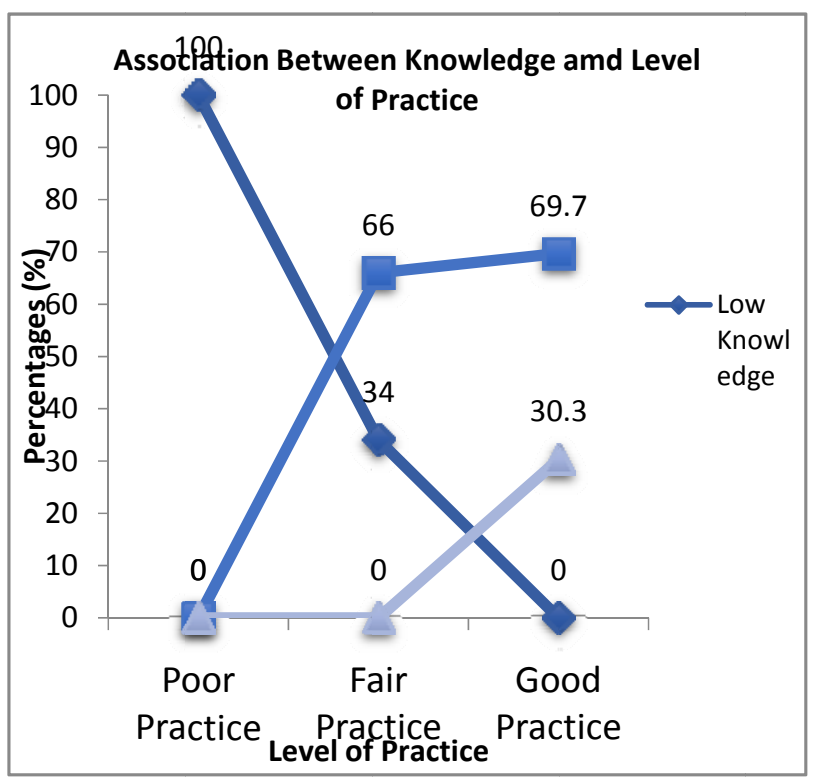

Graph 5. Association between knowledge and level of practice against dengue fever prevention.

Attitude had significant association between the levels of practice behaviors regarding dengue infection $(\mathrm{p}=0.00)$. Attitude had significant association between the levels of practice behaviors regarding dengue infection $(\mathrm{p}=0.00)$.

Table 13. Association between attitude and level of practice behaviors against dengue fever prevention.

\begin{tabular}{|c|c|c|c|c|}
\hline \multirow{2}{*}{ Level } & \multicolumn{4}{|c|}{ Attitude } \\
\cline { 2 - 5 } & $\begin{array}{c}\text { Negative } \\
\text { No. (\%) }\end{array}$ & $\begin{array}{c}\text { Neutral } \\
\text { No. (\%) }\end{array}$ & $\begin{array}{c}\text { Positive } \\
\text { No. (\%) }\end{array}$ & $\begin{array}{c}\text { Total } \\
\text { No. (\%) }\end{array}$ \\
\hline Poor practice & $29(100)$ & $0(0)$ & $0(0)$ & $29(100)$ \\
\hline Fair practice & $116(75.8)$ & $37(24.2)$ & $0(0)$ & $153(100)$ \\
\hline Good practice & $0(0)$ & $132(65.7)$ & $69(34.3)$ & $201(100)$ \\
\hline Total & $145(37.9)$ & $169(44.1)$ & $69(18.0)$ & $383(100)$ \\
\hline $\mathbf{p = 0 . 0 0 0}$ & \multicolumn{5}{|c}{} \\
\hline
\end{tabular}




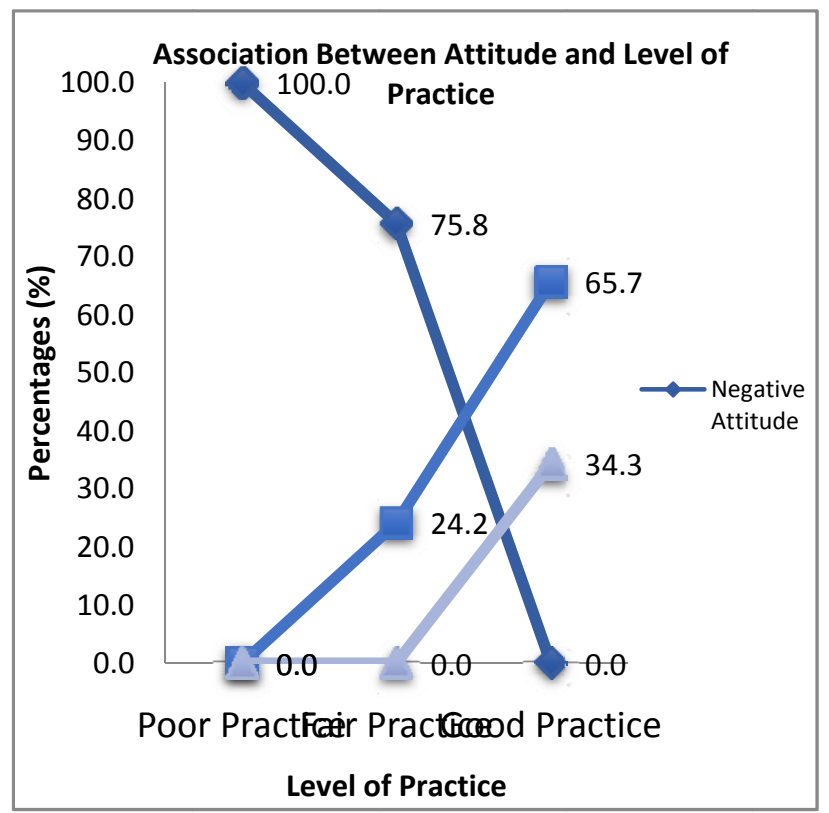

Graph 6. Association between attitude and level of practice behaviors against dengue fever prevention.

\section{Discussion}

\section{Socio-demographic characteristics of respondents}

The results of this study showed that education level were significant associated with level of attitudes and practices. Graduates from tertiary education and postgraduate had good practices towards dengue infection. This might be because they were aware the importance of practicing dengue prevention. In addition, the graduates and post-graduates had neutral attitudes towards dengue fever infection.

In this study, television was the most common sources of information regarding dengue fever $(72.1 \%)$, so the importance of practising dengue prevention should be emphasized through television. This is similar to previous studies whereby television was the most popular source of information about dengue fever (Sultana Habibullah et al, 2013). However, another study in Lao PDR reported that friends and relatives (43.9\%) were the main source of information regarding dengue fever.

\section{Knowledge about dengue fever}

The mean knowledge score was found to be 91 from a possible 14 points with a standard deviation of 1.76 . More than half of the respondents $(62.9 \%)$ had moderate scores and only $15.9 \%$ of them had high knowledge regarding dengue fever. This might be due to the education information for the public was insufficient and not readily available.

Areas of high level of knowledge:

Almost all of the respondents (97.4\%) answered correctly on the question that empty stagnant water from old tires, trash cans, and flower pots can be mosquito breeding sites. Similarly, a study also found that $93 \%$ of the respondents knew that stagnant water is the main source for mosquito breeding (AbdoRadman et al., 2013).

Regarding the principal mosquito vector for dengue fever, $91.6 \%$ of the respondents were aware that was Aedesaegypti. This was consistent with the study conducted by Anita AbdRahman et al (2014) which recorded majority of them (91.5\%) knew that dengue fever was caused by Aedesmosquito.

Areas of knowledge deficit:

According to World Health Organization (WHO), Aedes mosquitoes usually bite 
South American Journal of Public Health

Volume 4, Issue 1, 2016

during the day. However, refer to Table 3 , only $24.5 \%$ of the respondents answered correctly that mosquitoes transmitting dengue infection bites only during day time. This finding was consistent with the findings of previous study which indicate $44 \%$ of rural and only $9.5 \%$ of urban population knew the day biting habit of dengue mosquito (Shoba et al., 2014). This is important to the public on the timing of the use of protective measures from mosquito bites. Hence, it was recommended that dengue prevention educational programs should added focus on this important topic.

On top of this, less than half of the respondents (37.1\%) were aware that dengue infection can occur in all season, not only during the rainy season.

Among the research population, knowledge had significant association with the practice of dengue prevention. Previous studies have found similar associations between knowledge and practices (Benthem et al., 2002; Itrat et al., 2008; Ibrahim et al, 2009).

\section{Attitude Towards Dengue Fever}

The mean survey score for attitude about dengue fever prevention was found to be 41.93 from a possible 60 scores with a standard deviation of 4.99. Based on Likert scale, majority of the respondents had neutral attitude.

$53.8 \%$ of the respondents disagreed that dengue fever was a disease that cannot be prevented and more than half of the respondents (77.6\%) agreed that they were the important people in preventing dengue fever. This was similar to a study conducted by Binsaeed A.A et al (2015) that $93.2 \%$ of the respondents believed that dengue fever can be prevented and controlled and $78.5 \%$ of them recognized themselves have an important role to play in dengue fever prevention.

However, there is a deficit in the respondents' attitude towards dengue fever. Although $77.0 \%$ of the respondents agreed that the only method of controlling and preventing dengue and dengue hemorrhagic fever is to combat the vector mosquitoes, about $11.2 \%$ of them believed the elimination of larval breeding sources is a waste of time and very complicated. This findings was consistent with previous study by Acharya et al.(2005).

This present study found a significant association between attitudes and both level of education and ethnicity. Tan Kok Leong et al. (2014) found similar findings. Malay ethnicity and with graduate education level showed positive attitude.

There was a significant association with attitudes and practice of dengue fever prevention in this study. However, this was contrast with a study of Hairi et al,(2003) found out there was no significant association seen between attitudes and preventive practice on dengue.

\section{Conclusion}

It was evident from this study that television was the most important sources of information on dengue fever among the population. Although knowledge regarding the breeding and preventive methods was essential but alone it was not enough to achieve mosquito control unless it was translated into practice.

The level of knowledge regarding dengue fever was still insufficient among the population of Bandar Maharani, Muar, but their level of practice was good.

Ethnicity and education level were significantly associated with level of attitude and practice. Regarding the knowledge and attitude toward dengue fever were positively associated with the practice prevention.

\section{Recommendation}

1. Government authorities should strengthen the educational campaign regarding dengue through social media to increase awareness and knowledge regarding dengue and preventive measures to reduce the incidence of dengue fever. 
2. Information, education and communications (IECs) materials maybe provided in areas like schools and health centres making it more accessible for the residents to obtain.

3. Health personnel should be trained to give appropriate counselling in an effort to change certain deeply ingrained traditional behaviours like domestic water storage without proper cover.

4. Emphasis should be placed on the limitations, such as seeking early treatment as soon as dengue signs and symptoms are noticed.

5. The unique traditional community collaborative activity (gotong-royong) frequently practiced in rural villages should be promoted in urban communities as well.

\section{References}

[1]. Acharya A, Goswami K, Srinath S, Goswami A. Awareness about dengue syndrome and related preventive practices amongst residents of an urban resettlement colony of south Delhi. J Vector Borne Dis 2005;42:122-7.

[2]. Anita AbdRahman, Huda Zainuddin, Halimatus Sakdiah Minhat, et al. Community perception toward Dengue and Dengue Prevention Program among residences of a rural settlement in Jempol, Negeri Sembilan. International Journal of Public Health and Clinical Sciences September/October 2014; 1(1): 13-23.

[3]. Benthem VBH, Khantikul N, Panart K, Kessels PJ, Somboon P, Oskam L. Knowledge and use of prevention measures related to dengue in northern Thailand. Trop Med Int Health 2002; 7: 993-1000.

[4]. Binsaeed A. A, Sahli A. A, Noureldin E. M, Mohammed W. S, Dafalla O. M, Dahlan A, Kasule O. H, Alsheikh A. A. Knowledge, attitudes and preventive practices of dengue fever among secondary school students in Jazan, Saudi Arabia. Curr World Environ 2015; 10(3).

[5]. CDC. Dengue homepage. Available: www.cdc.gov/dengue/epidemiology/. Accessed 28 October 2015.

[6]. Chanthalay Sayavong, Jirapan Chompikul, Somsak Wongsawass et al. Knowledge, Attitude, Preventive Behaviors related to Dengue Vector Breeding Control Measures among Afukts in Communities of Vientiane, Capital of the Lao PDR. Journal of Interaction and Public Health March 2015; Vol. 8: 466-473.

[7]. Gupta, P., Kumar, P., Aggarwal, O.P. (1998). Knowledge, attitude and practices related to dengue in rural and slum areas of Delhi after the dengue epidemic of 1996. Journal of Communicable Disease 1998; 30(2): 107-112.

[8]. Ibrahim NKR, Al-Bar A, Kordey M, Al-Fakeeh A. Knowledge, attitudes and practices relating to dengue fever among females in Jeddah high schools. J Infect Public Health 2009; 29:30-40.

[9]. Itrat A, Khan A, Javaid S, et al. Knowledge, awareness and practices regarding dengue fever among the adult population of dengue hit cosmopolitan. PLoS One 2008; 9: e2620.

[10]. K. Ravi Kumar, G. Gururaj. Community Perception Regarding Mosquito-borne Diseases in Karnataka State, India. Dengue Bulletin 2005; 29: 157-164.

[11]. Li Ping Wong, Sazaly Abu Bakar, Karuthan Chinna. Community Knowledge, Health Beliefs, Practices and Experinces Related to Dengue Fever and Its Association with IgGSeropositivity. PLOS Neglected Tropical Diseases May 2014; 8(5): 1-13.

[12]. Madiha Syed, Taimur Saleen, Umme-Rubab Syeda et al. Knowledge, Attitudes and Practices Regarding Dengue Fever among Adults of High and Low Socioeconomic Groups. J Pak Med. Assoc. March 2010; 60(3); pg 243-247.

[13]. Ministry Of Heath Malaysia. Clinical Practice Guideline on Management of Dengue Infection in Adults: Quick Reference for Healthcare Providers 2010. (Revised 2nded).

[14]. Nahida Ahmed. Knowledge, attitude and practice of dengue fever prevention among the people in Male', Maldives. College of Public Health Sciences, Chulalongkorn University; 2007.

[15]. Nalongsack S, Yoshida Y, Monta S, Sosouphanh K, Sakamoto J. Knowledge, attitude and practice regarding dengue among people in Pake, Laos. Nagoya J Med Sci 2009; 6:62-7.

[16]. Pang T, Lam KSK. The immunopathogenesis of dengue hemorrhagic fever. Immunol Today1983;4(2):46-9.

[17]. Pracheth Raghuveer, Mayur S Sherkhane, Jayprakash V Chowti, Comparative Study of Dengue Knowledge among Adults of Urban and Rural Population in India. International Journal of Health and Rehabilitation Sciences; 2(4): 222-229.

[18]. Rose NaniMudin. Dengue Incidence and the Prevention and Control Program in Malaysia. The International Medical Journal Malaysia June 2015; 14(1): 5-9. 


\section{South American Journal of Public Health}

\section{Volume 4, Issue 1, 2016}

[19]. Sami Abdo Radman Al-Dubai, Kurubaran Ganasegaran, Mohanad Rahman Alwan, et al. Factors Affecting Dengue Fever Knowledge, Attitudes and Practices among Selected Urban, Semi-urban and Rural Communities in Malaysia. Southeast Asian J Trop Med Public Health Jan 2013; 44(1); pg 37-49.

[20]. Samina Qadir, Iftikhar Ahmad, Muhammad Naeem Akhtar et al. Knowledge, Attitude and Practice About Dengue Fever among Local Population. Gomal Journal of Medical Science April-June 2015; 13(2): 87-90.

[21]. Shepard DS, Lees R, Ng CW, Undurrage EA, Halasa Y, Lum L. Burden of Dengue in Malaysia. Retrieved 28 October 2015 from http://people.brandeis.edu/ shepard/Report_dengue_in_Malaysia_v50.pdf.

[22]. Shobha, Saraswathi S, Amita Mukhopadyay et al. A Cross Sectional Study of Perception and Preventive Practices, regarding Dengue Disease among Population of Bangalore District, South India. Asian Journal of Pharmaceutical and Health Science 2014; 4(3):1056-1061.

[23]. Sultana Habibullah and Junaid Ashraf. Perceptions and Practices for the Control of Dengue Fever in KarachiA School Based Survey. Pakistan Journal of Medical Research 2013; 52(4): 102-105.

[24]. Tan Kok Leong. Knowledge, Attitude and Practice on Dengue among Rural Communities in Rembau and Bukit Pelanduk, Negari Sembilan, Malaysia. International Journal of Tropical Disease and Health 2014; 4(7): 841-848.

[25]. WHO. Dengue and severe dengue 2014. Available: http://www.who.int/mediacentre/factsheets/fs117/en/. Accessed 28 October 2015. 